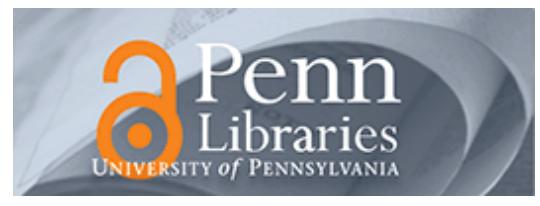

University of Pennsylvania

ScholarlyCommons

Accounting Papers

Wharton Faculty Research

$12-2011$

\title{
Conference Presentations and the Disclosure Milieu
}

Brian J. Bushee

University of Pennsylvania

Michael J. Jung

Gregory S. Miller

Follow this and additional works at: https://repository.upenn.edu/accounting_papers

Part of the Accounting Commons

\section{Recommended Citation}

Bushee, B. J., Jung, M. J., \& Miller, G. S. (2011). Conference Presentations and the Disclosure Milieu. Journal of Accounting Research, 49 (5), 1163-1192. http://dx.doi.org/10.1111/j.1475-679X.2011.00426.x

This paper is posted at ScholarlyCommons. https://repository.upenn.edu/accounting_papers/61

For more information, please contact repository@pobox.upenn.edu. 


\title{
Conference Presentations and the Disclosure Milieu
}

\begin{abstract}
Conference presentations differ from other voluntary disclosures in that the audience for the disclosure is co-located with managers in a well-defined physical and social setting, or "disclosure milieu." The milieu affects the degree to which conference participants can update their prior beliefs about the firm with information signals obtained through interactions with management and other informed participants. While the average abnormal stock return and volume reactions to presentations are positive, there is a great deal of cross-sectional variation as indicated by negative median reactions. We find that conference characteristics that determine the nature of the audience and its interactions, such as sponsor, location, size, and industry-focus, are significantly associated with the market reaction, consistent with the disclosure milieu explaining the cross-sectional variation in the information content of the presentation. We also find that conference characteristics explain changes in subsequent analyst and institutional investor following, consistent with the disclosure milieu creating differences in access to management by potential new investors and analysts.
\end{abstract}

Disciplines

Accounting 


\title{
Conference Presentations and the Disclosure Milieu
}

\author{
Brian J. Bushee \\ The Wharton School \\ University of Pennsylvania \\ 1300 Steinberg-Dietrich Hall \\ Philadelphia, PA 19104-6365 \\ bushee@wharton.upenn.edu
}

\author{
Michael J. Jung \\ Leonard N. Stern School of Business \\ New York University \\ 44 West $4^{\text {th }}$ St. \\ New York, NY 10012-1126 \\ mjung@stern.nyu.edu \\ Gregory S. Miller \\ Stephen M. Ross School of Business \\ University of Michigan \\ 701 Tappan St. \\ Ann Arbor, MI 48109-1234 \\ millerg@umich.edu
}

Journal of Accounting Research (2011), Vol. 49, No. 5, pp 1163-1192

\begin{abstract}
We thank an anonymous reviewer, Doug Skinner (editor), Bill Baber, Bill Cready, Victoria Dickinson, Bjorn Jorgensen, Dawn Matsumoto, Jayanthi Sunder, Ro Verrecchia, and workshop participants at the 2008 American Accounting Association Annual Meeting, Cornell University, Georgetown University, Harvard Business School, London Business School, Northwestern University, the Stanford University Summer Camp, University of Colorado, University of Florida, University of Miami, University of Michigan, University of Minnesota, University of North Carolina, University of Pittsburgh, University of Texas at Dallas, and University of Washington for helpful comments and suggestions. We thank Maria Aguilar Paredes, Lyndsey Bunting, Jack Chen, Ashley Hamilton, Sammi Liu, and Josh Sandberg for research assistance. We are grateful for the funding of this research by the Wharton School and the Michael R. and Mary Kay Hallman Fellowship.
\end{abstract}




\title{
Conference Presentations and the Disclosure Milieu
}

\begin{abstract}
Conference presentations differ from other voluntary disclosures in that the audience for the disclosure is co-located with managers in a well-defined physical and social setting, or "disclosure milieu." The milieu affects the degree to which conference participants can update their prior beliefs about the firm with information signals obtained through interactions with management and other informed participants. While the average abnormal stock return and volume reactions to presentations are positive, there is a great deal of cross-sectional variation as indicated by negative median reactions. We find that conference characteristics that determine the nature of the audience and its interactions, such as sponsor, location, size, and industry-focus, are significantly associated with the market reaction, consistent with the disclosure milieu explaining the cross-sectional variation in the information content of the presentation. We also find that conference characteristics explain changes in subsequent analyst and institutional investor following, consistent with the disclosure milieu creating differences in access to management by potential new investors and analysts.
\end{abstract}




\section{Introduction}

Conference presentations are a prevalent form of managerial communication, providing one of the few settings that allow face-to-face interactions among managers, investors, analysts, and other stakeholders. Conferences typically bring together a large number of companies to the same location for a series of presentations to an audience invited by the conference sponsor. As a result of this co-location, conference presentations differ from other types of voluntary disclosure, such as press releases and conference calls, because they occur within a well-defined physical and social setting, which we refer to as the "disclosure milieu." Each conference setting creates a disclosure milieu that determines the composition of the audience and the extent of the interactions among managers and the audience in the same place and time as the manager makes the disclosure. We predict that the disclosure milieu influences the ability of participants to revise their beliefs about the firm and, hence, the market reaction to the presentation.

Prior work suggests that the audience for a disclosure could affect its information content due to differences in investors' private information, consensus in beliefs, and ability to interpret disclosures (Holthausen and Verrecchia [1990], Indjejikian [1991], Kim and Verrecchia [1994]). The disclosure milieu heightens these potential audience effects by bringing together participants with private information to the same location and facilitating information transfers through explicit discussions with managers and other participants, higher-order belief formation, and assessment of nonverbal cues. Thus, the milieu affects the degree to which participants can Bayesian update their prior beliefs about the firm with information signals obtained from management and other participants before, during, and after the presentation. In the conference setting, the disclosure milieu is determined by conference characteristics such as sponsor, location, size, and industry-focus. We use a sample of 95,105 conference presentations that 
exhibit cross-sectional variation in these characteristics to test whether the disclosure milieu predictably explains the absolute stock return and share turnover reaction to the presentations and the subsequent changes in following by institutional investors and analysts.

Conference presentations typically last less than an hour and include a mix of prepared remarks and question and answer periods. While Regulation Fair Disclosure (Reg FD) does not preclude limited-access presentations, managers are still subject to selective disclosure restrictions (Cooley Godward [2000]). Presentations are not tied to another major information event (e.g., earnings announcements) because conference sponsors must schedule the conference well in advance and at a time when a large number of managers can attend. As a result, the goal of the conference presentation is often to provide a broader, more qualitative view of the firm's strategy and operations. Managers have incentives to present at conferences to improve the firm's visibility; to meet the demands of stakeholders for access to top management; to solidify business relationships with the conference sponsor; and to avoid negative attributions that could arise from failing to attend a conference at which most of the firm's peers are represented.

We measure the information content of the presentation using abnormal absolute returns and abnormal share turnover in the three days around the presentation. We find significant mean increases in abnormal absolute returns and turnover during the presentation window that represent 5-10\% increases over the prior 90-day estimation period. However, the median values are negative (and larger in magnitude in the case of absolute returns) because only 40-45\% of the firms experience greater absolute returns and turnover than in the estimation period. The crosssectional variation in these univariate effects is not surprising because managers generally do not disclose new information during presentations; rather, most of the information content comes 
from the private information of the audience. Our examination of the disclosure milieu highlights the factors that drive these cross-sectional differences in market response.

We use the conference sponsor, location, size, and industry-focus to measure differences in the disclosure milieu. We find that the disclosure milieu is significantly associated with the information content of the presentation, controlling for a large number of firm characteristics and for concurrent information releases. Presentations at conferences sponsored by product market intermediaries and top brokerage firms exhibit greater market reactions than conferences hosted by small brokerage firms, analyst societies, stock exchanges, and IR firms. For product market conferences, this finding is consistent with management having incentives to disclose new information to business partners and with the presence of an audience with product-specific private information. For top brokerages, the result is consistent with their conferences attracting a larger pool of sophisticated investors with greater potential private information.

We also find that presentations at conferences held in money centers and destination resorts generate more information content than those held in other US cities or outside the US. Information content is also positively associated with conference size. The results for money center and large conferences reflect a larger audience of sophisticated investors with greater private information and more higher-order belief formation. While destination conferences typically draw smaller crowds, they allow for more interactions among the participants who remain at the venue longer; thus, this finding reflects increased information content arising from the intensity of interactions. Presentations at industry-focused conferences convey more information than at broad conferences, consistent with the audience having more industryspecific private information that can facilitate information transfers across presentations. 
Combined, these results show that the disclosure milieu affects the information content of the presentation, highlighting the role of the audience and its interactions in the disclosure process.

Next, we examine how the disclosure milieu affects changes in following by analysts and institutional investors. We control for the information content of the presentation so that the composition of the audience and its interactions will be the major determinants of whether a presentation attracts new analysts and investors. We find that analysts are more likely to increase following of firms presenting at industry-focused conferences, consistent with the industry-based structure of analyst coverage. Analysts are less likely to increase following after presentations at product market conferences or top brokerage conferences, consistent with analysts not being the target audience in either of these settings. Product market conferences are not structured to facilitate interactions between managers and analysts, and top brokerage conferences generally exclude analysts from competing brokerage firms.

Institutional investors are more likely to increase ownership of firms presenting at conferences hosted by top brokerage firms and at large conferences. These results suggest that institutional investors are more likely to attend conferences that provide preferential access to a large number of firms, thus reducing the costs of learning about these firms and their managers. ${ }^{1}$ Moreover, the finding that top brokerage conferences are associated with larger changes in institutional ownership, but smaller changes in analyst coverage, provides strong evidence that the disclosure milieu (e.g., access to management) drives the results, rather than an omitted factor correlated with both conference characteristics and following by analysts and investors.

This paper contributes to the voluntary disclosure literature by providing evidence that the physical and social setting in which a disclosure takes place - the "disclosure milieu"-

\footnotetext{
${ }^{1}$ As further evidence of the importance of access to management, Bushee, Jung, and Miller [2011] find that investors tend to execute larger, more profitable trades during periods when they have direct, private access to managers. They also find that this result is distinct from the milieu effects shown in this paper.
} 
influences the market reaction to disclosure. Unlike most verbal or written disclosures, conference presentations occur within a disclosure milieu that determines the audience and its degree of interactions. In doing so, the milieu affects the nature and degree of private information that is impounded into price through mechanisms such as higher-order beliefs and nonverbal cues that can only be obtained through co-location of managers and other informed participants. The milieu also affects the firm's ability to attract new analysts and institutional investors by influencing the pool of participants and their access to management. Our findings suggest that examining the disclosure milieu could provide new insights into the market response to voluntary disclosure.

The next section reviews prior literature and provides some background on conferences to motivate our predictions. Section 3 describes the sample and defines the variables used in the analyses. We present results on the stock return and trading volume reactions to presentations in Section 4 and on changes in institutional investor and analyst following subsequent to presentations in Section 5. We offer conclusions in Section 6.

\section{Motivation and Predictions}

\subsection{Prior Literature}

A large literature finds significant effects of voluntary disclosure on stock returns, trading volume, and following by analysts and institutional investors. Much of this literature focuses on written disclosures or disclosure indices (e.g., Lev and Penman [1990], Skinner [1994], Lang and Lundholm [1996a], Healy, Hutton, and Palepu [1999], Bushee and Noe [2000], Hutton, Miller and Skinner [2003]). Studies of conference calls provide evidence that interactive verbal communications are an important source of information for investors and analysts (Frankel, Johnson and Skinner [1999], Bowen, Davis and Matsumoto [2002], Bushee, Matsumoto and 
Miller [2003], [2004]). However, in conference calls, there is no possibility for interaction before or after the call, and managers can control the queuing of questioners to reward or punish analysts (Mayew [2008]).

In recent years, managers have increasingly added conferences presentations to their disclosure activities (Jackson [2007]). Despite the growth in conferences, only one published study examines these presentations. Francis, Hanna, and Philbrick [1997] examine a sample of 1,199 presentations to the New York Society of Security Analysts during the nascent period for management presentations (1986-1992). They find significant positive returns on the day of the presentation, particularly for undervalued firms, consistent with the presentation mitigating visibility issues. They also find an increase in analyst following after the presentation, but no relation with forecast accuracy. These findings indicate the information potential of conference presentations. However, because the common conference format at the time was a single sponsor and location with generally few firms presenting in each conference, there was no opportunity to study cross-sectional variation in the audience or its degree of interactivity.

\subsection{Conference Presentations}

Subsequent to the Francis, et al. [1997] sample period, the number and variety of organizations sponsoring conferences have grown substantially. Between 1999 and 2007, there were over 95,000 presentations at more than 5,400 conferences hosted by over 800 organizations. Meanwhile, the number of analyst society conferences has declined over time dropping from 6\% of our sample in 1999 to $1 \%$ in 2007. Most conferences are now hosted by analysts through their brokerage firms. ${ }^{2}$

\footnotetext{
${ }^{2}$ By sponsoring their own conferences, analysts can provide access to only the brokerage firm's best clients. A recent survey indicated that one-third of the commission payments used to compensate brokerage firms is to reward brokers for corporate access, including the facilitation of meetings with company management and invitations to conferences (Greenwich Associates [2010]).
} 
Conferences are publicized weeks in advance and are generally by invitation only. Reg FD does not preclude limited-access conferences; however managers are still subject to restrictions on selective disclosure of material information. ${ }^{3}$ To comply with Reg FD, companies often provide webcasts and/or concurrent public releases (e.g., Form 8-K filings). Presentations typically last 30 to 45 minutes and consist of management making prepared remarks and then taking questions. These presentations focus on a more overarching view of the company and its strategy, without having to explain a recent information event. ${ }^{4}$ Presentations also help managers develop a commitment to transparency through face-to-face interactions, which many IR professionals view as the most crucial part of a firm's communication strategy (Bushee and Miller [Forthcoming]). Participants attending a conference potentially gain more information than those who only listen to webcasts because their co-location with managers and other participants allows them to assess the veracity of managers' statements through visual and verbal cues, to judge other participants' reactions to the discussion, and to continue conversations with managers and other participants outside of the presentation. ${ }^{5}$

The co-location of managers and participants creates a "disclosure milieu" in which the audience and its interactions affect the information content of the presentation. Prior work suggests that the audience for a disclosure could affect its information content due to differences

\footnotetext{
${ }^{3}$ The SEC does not define "material information" and firms have some latitude to discuss details of the business to fill in the "mosaic" of information without violating Reg FD (Cooley Godward [2000]). In 2005, a district court judge dismissed a Reg FD action against Siebel Systems, saying (in part) "Regulation FD does not require that corporate officials only utter verbatim statements that were previously publicly made." Further, the judge argued that "Although stock movement is a relevant factor to be considered in making the determination as to materiality, it is not, however, a sufficient factor alone to establish materiality" and that "the actions taken by those in attendance at the speaking engagement, although a relevant consideration, do not change the nature or content of statements" (SEC v. Siebel Systems, et al. [2005]). This ruling shows the difficultly in determining if Reg FD has been violated. ${ }^{4}$ As one asset manager put it, "what we're trying to do is build a jigsaw puzzle... [we] don't go to conferences to be told how much a company is going to earn next quarter. [We] go to uncover the fundamentals of the company ....and trends that will change dynamics in the industry five years ahead" (Dow Jones Newswires [2001]).

${ }^{5}$ Consistent with the importance of co-location, attempts to hold "virtual" conferences have failed. In a virtual conference, the sponsor sets a schedule of interactive webcast presentations by managers without any co-location, saving the costs of time and travel. These presentations peaked at 63 in 2002 and have dropped to only 18 in 2007.
} 
in investors' private information, consensus in beliefs, and ability to interpret disclosures (Holthausen and Verrecchia [1990], Indjejikian [1991], Kim and Verrecchia [1994]). A large number of participants with private information and greater ability to ask questions of managers and other participants should increase the "informedness" of the presentation (Holthausen and Verrecchia [1990]). Participants can supplement their explicit information gathering with higher-order beliefs formed by observing the behavior of other participants. Morris and Shin [2003] show a "publicity multiplier" effect in which "public briefings have a larger impact on the market than bilateral briefings with the same information because they automatically convey to participants not only information about market conditions, but also valuable information about the beliefs of the other participants." Co-location also allows participants to use nonverbal cues to assess the credibility of any information. Research on nonverbal cues finds that a large percentage of information is communicated through body language, facial expressions, and vocal tone (Mehrabian [1972], Andersen [2008], Mayew and Venkatachalam [Forthcoming]). ${ }^{6}$ Thus, the information content of a conference presentation is a not only a function of explicit information releases, but also the degree to which the disclosure milieu facilitates information transfers, formation of higher-order beliefs, and the assessment of nonverbal cues.

\subsection{Predictions}

We develop predictions for which conference characteristics create a disclosure milieu that provides a larger potential for belief revision and, hence, greater information content to the presentation. We also form predictions for which conference characteristics facilitate greater increases in following by analysts and institutional investors, who use the conference interactions to assess management's credibility and commitment to transparency. We illustrate the

\footnotetext{
${ }^{6}$ Some institutional investors actively evaluate nonverbal information by hiring ex-CIA or ex-FBI agents to watch management for signals of extreme stress or dishonesty (Rodier [2010]).
} 
conference characteristics by referring to examples in Panel A of the Appendix, which provides a list of conferences taking place on October 3, 2007.

\subsubsection{Conference Sponsor}

The conference sponsor influences the disclosure milieu by inviting the firms and audience to the conference. We divide sponsors into three categories: product market, top brokerage firm, and other capital market (see Panel B of the Appendix for details). "Product market" conferences are sponsored by non-profit trade associations (e.g., Independent Petroleum Association of America), consulting firms (e.g., Sachs Associates) and media outlets (e.g., CFO.com), with the goal of facilitating management interactions with business partners. Investors and analysts can attend as well, but they do not necessarily receive direct access to managers. Managers use these presentations to provide their view of the industry, and they often unveil new technologies, products, or business relationships. Capital market conferences focus on meeting investor and analyst demands for access to management. The presentations are designed to provide an overview of the firm's operations and strategy and allow participants to fill-in their "mosaic" of information about the firm. Within this group, "top brokerage firm" conferences (e.g., Bear Stearns) are organized by the analysts in the brokerage firm and attract a wide range of institutional investors with a large amount of private information, but generally exclude analysts from other brokerage firms. In contrast, "other capital market" conferences are hosted by small brokerage firms (e.g., William Blair \& Co.), stock exchanges (e.g., Borsa Italia), analyst societies (e.g., Consumer Analyst Group of New York), and investor relations firms. They tend to be smaller conferences focused on improving visibility for participating firms.

We expect that presentations at product market conferences have greater information content than presentations at other capital market conferences due to managers' incentives to 
disclose new product information and to the ability of investors to assess the reactions of product market stakeholders. We also expect that presentations at top brokerage conferences have greater information content than presentations at other capital market conferences due a greater number of sophisticated investors with private information. Controlling for any information content of the presentation, we expect that product market conferences lead to smaller increases in analyst and institutional investor following because they are not designed to foster interaction among managers, analysts, and investors. For top brokerage conferences, we predict that the combination of more large institutional investors and general exclusion of outside analysts leads to a greater (smaller) effect on institutional investor (analyst) following.

\subsubsection{Geographic Location}

The geographic location of the conference affects the disclosure milieu by influencing the size of the audience and the degree of interactions outside of the presentation. We divide location into four groups: money centers, destinations, other US cities, and non-US cities (see Panel C of the Appendix). "Money center" conferences are held in New York, Boston, San Francisco, and Chicago, where a substantial number of buy-side investors and analysts are based. The proximity to a large pool of capital market participants draws a larger audience, increasing both the informedness of the presentation and the number of potential new investors and analysts. "Destination" conferences are held in locations such as Florida, Arizona, Southern California, and Las Vegas that require both investors and managers to travel long distances. Due to the time commitment for travel and the desired location, participants are more likely to stay at the conference venue over a multi-day period, increasing the number of potential interactions between managers and investors. Conferences held in "other US" cities tend to focus on either regional firms or a certain industry (e.g., Marcus Evans Defense Conference in Arlington, VA). 
Finally, conferences held in "non-US cities" provide a venue to help firms overcome home bias and attract foreign investment (Bradshaw, Bushee and Miller [2004]). However, such conferences are less likely to attract US investors and analysts.

We expect that presentations at money center and destination conferences have greater information content and subsequent increases in analyst and institutional investor following than presentations at other US cities due to their larger audiences and greater opportunities for interactions, respectively. We expect lower information content, and less impact on US analysts and investors, at non-US conferences as the goal is to increase visibility among foreign investors.

\subsubsection{Other Characteristics}

Conferences vary in the number of firms presenting, which influences the disclosure milieu by determining the size of the audience. Large conferences provide a low-cost way for participants to view a large number of firms in a short time period and, thus, they attract more market participants. Presentations at large conferences should produce larger stock market reactions if they allow a greater number of investors to have access to management, increasing the informedness of the presentation. Larger conferences also provide more opportunity for information transfer across presentations due to the greater number of firms. We expect conference size to be positively associated with both the information content of the presentation and the subsequent change in institutional investor and analyst following.

The number of industries represented at the conference affects the disclosure milieu by influencing the potential amount of information transfer. Some conferences are focused on one industry (e.g., Credit Suisse Aerospace and Defence Conference), while others are focused on an investment style (e.g., William Blair Micro-/ Small-Cap Growth Conference). Industry conferences are more likely to attract a large number of analysts and investors with specialized 
knowledge of that industry. Thus, for any given firm, the percentage of the audience with potential interest in the firm is greater than at a broad conference. This greater pool of interested attendees with industry-specific knowledge should produce a larger stock market reaction to the presentation due to the informedness effect and greater information transfers (Lang and Lundholm [1996b]). Also, because analysts and investors specialize in sectors, presentations at industry-focused conferences should also be more effective at increasing analyst and institutional investor following. We expect greater information content and larger increases in investor and analyst following for presentations at industry-focused conferences.

While the number of recent conference presentations a company has given is not a characteristic of the disclosure milieu, we expect that more prior presentations will reduce the potential for new insights to investors' private information. However, multiple presentations indicate a commitment to transparency and allow managers to interact with more potential investors and analysts, increasing the likelihood that some decide to follow the firm. We predict that more frequent presentations will be associated with less information content, but greater increases in analyst and investor following.

One caveat to these predictions is that the disclosure milieu could also proxy for managers' incentives to selectively disclose new material information. While such actions would violate Reg FD, we cannot dismiss this possibility. Thus, our predictions are conditional on the assumption that any potential selective disclosure is not correlated with these conference characteristics. However, if the results were driven solely by selective disclosure, it would still imply that the disclosure milieu is important, but as a mechanism for eliciting private disclosure rather than as a mechanism for the audience to affect the information content of the conference. ${ }^{7}$

\footnotetext{
${ }^{7}$ Bushee, et al. [2011] use a sample of US capital market conferences with transcripts to identify situations in which investors have formal off-line access to managers in a one-on-one or breakout session. They find an increase in
} 


\section{Sample and Variables}

\subsection{Sample}

We obtain data on conference presentations between 1999 and 2007 from the Thomson Reuters' Street Events database. For each presentation, Thomson provides the firm name, ticker, conference name, date, time, and location. ${ }^{8}$ Thomson collects this data from the conference sponsors and presenting companies to alert its clients of upcoming conferences and to provide webcasts. Over $57 \%$ of the conferences are one-day events, $26 \%$ are two-day events, and $15 \%$ are three-to-five-day events. After eliminating presentations by individuals unaffiliated with companies, panel discussions, annual meetings, analyst meetings that are misclassified as conference presentations (all in 1999), and presentations where the conference was cancelled (most were right after 9/11/2001), we have 120,991 conference presentations by 13,346 firms.

Next, we obtain stock return, trading volume, and industry data from the CRSP database. The requirement of CRSP data eliminates 15,886 presentations given by 6,085 firms, which include private firms, OTC Bulletin Board and Pink Sheets firms, and non-US firms. Finally, we obtain institutional investor ownership data from the Thomson Reuters Form 13F database, analyst following data from the Thomson Reuters I/B/E/S database, and data on firm characteristics from the Compustat database. After requiring this data, we have a final sample of 95,105 presentations by 5,910 firms at 5,464 conferences sponsored by 849 organizations.

average trade sizes and potential trading gains during the hours when off-line access is provided. While their results could indicate selective disclosure, it could also be consistent with investors using this access to update private information by asking for specific qualitative information or by assessing nonverbal cues. In any case, they find that the conference characteristics examined in this paper do not proxy for formal offline access to managers.

${ }^{8}$ The Thomson data is indexed by the current company ticker symbol, with acquired firms listed under the acquirer's ticker. In 1999 and since 2002, Thomson provides the company name at the time of the presentation, which allows us to identify the firm making the presentation. When Thomson does not list the company name, we check Factiva for press releases to identify the firm presenting. When we were unable to classify the presentation using Factiva, we classified it under the acquiring firm, which adds noise to some of the earlier data. 
Table 1 presents a breakdown of the sample by conference characteristics. Panel A shows the sponsors and locations of the presentations by calendar year. The number of conference presentations has grown over time, with a slight reversal in 2007. This general upward trend is attributable to both an increase in the number of presentations and an increase in Thomson's coverage of them. The panel shows that about $11 \%$ of the presentations are at conferences focused on product markets, whereas the remaining $89 \%$ are roughly split between top brokerages and other capital market conferences. Money centers are the most common location for conference presentations (65\%), followed by destinations (22\%), other US cities (8\%), and non-US locations (6\%).

Panel B reports the number of industry-focused conferences and their distribution across sponsors and locations. We define an industry-focused conference as having fewer than 4 industries represented. ${ }^{9}$ About $28 \%$ of the conferences are industry-focused, suggesting that sponsors usually include a broad number of industries in conferences, likely to increase potential attendance by investors. Almost $60 \%$ of product-market conferences are industry-focused, which is expected based on their goal of cultivating business relationships. Industry-focused conferences comprise an above-average percent of those held in other US cities (35\%) and outside the US (57\%), and a below-average percent of destination conferences (18\%). Panel C presents a cross-tabulation of sponsors and locations. Product market conferences are more likely to be held at destinations than capital market conferences, which tend to be held in money centers. However, the table shows a large amount of variation across sponsors and locations. Panel D of Table 1 shows the Fama-French industry classification for our sample firms. Four industries account for $63 \%$ of our sample observations: Business Services, Health Care,

\footnotetext{
${ }^{9}$ We define industry using the 30-industry classification on Ken French's website that was used in Brennan, Wang, and Xia [2004]. Our results are not sensitive to expanding the definition to be fewer than five or six industries.
} 
Business Equipment, and Financial Services. Because of this concentration on technology and financial services firms, all of our tests include industry fixed effects.

\subsection{Variable definitions}

We measure the effect of the disclosure milieu with indicator variables for product market conferences (DPRODMKT), top brokerage firm conferences (DCAPMKT_TOP), money center conferences (DMONCEN), destination conferences (DDEST), conferences held outside of the US (DNONUS), and industry-focused conferences (DINDUS_CONF). Thus, the omitted group in the analyses is broad conferences hosted by other capital market sponsors in other US cities. The size of the conference (LCONFSIZE) is the log of one plus the number of presentations. We measure the frequency of prior conference presentations using the log of one plus the number of presentations given by the firm in the past 90 days (LPRIORPRES).

To control for the possibility that the market reaction surrounding a conference presentation is driven by a concurrent material information disclosure, whether provided at the conference or not, we collect earnings announcement dates, management forecasts, and Form 8$\mathrm{K}$ filings (including Form 6-K filings for foreign registrants) for our sample firms. We create an indicator variable (DINFO_EVENT) that equals one if any of these three events occur during the three-day conference presentation window and zero otherwise. ${ }^{10}$

We also control for a large number of firm characteristics that prior literature finds are associated with voluntary disclosure activity. For firm size, we include the log of market value of equity $(L M V) 30$ days before the presentation. We measure institutional investor following as the percent holdings by institutions $(P I H)$, defined as total shares owned by institutions divided

\footnotetext{
${ }^{10}$ This variable is not a perfect control for information released at a conference because a webcast of the presentation or open access with media coverage could satisfy the selective disclosure restrictions of Reg FD without a Form 8-K filing. For example, even though product market conferences are often used to disclose new product information, only $17 \%$ have an associated Form 8-K filing.
} 
by the total shares outstanding at the most recent calendar quarter end prior to the presentation.

We measure analyst following as the log of one plus the number of analysts issuing earnings forecasts $(L N A N L)$ for any horizon during the calendar quarter prior to the presentation. For both $P I H$ and $L N A N L$, we set the variable equal to zero for any period when the company is listed on an exchange but there is no data available. We measure recent stock market activity with the buy-and-hold market-adjusted stock return (ANNMAR) and the average monthly share turnover $(A N N T U R N)$ for the year prior to 30 days before the presentation. We also include an indicator variable for whether the company is headquartered outside the US (DFORFIRM).

We include a number of proxies for profitability, growth, and potential undervaluation, including the earnings-price ratio $(E P)$, dividend yield $(D P)$, the book-to-price ratio $(B P)$, the most recent change in net income $(C N I)$, and the most recent annual sales growth $(S G R)$. As a visibility proxy, we add an indicator variable for whether the firm is listed on a Standard \& Poor's index (SPINDX). We include the ratio of intangible assets to total assets (INTAN) to proxy for the complexity of a firm's business. We add a debt-to-assets leverage ratio ( $L E V)$, the standard deviation of stock returns (STD), and beta (BETA) to control for firm risk. We proxy for firm age with the log of the number of years the firm has been listed (LTIME).

Table 2 presents descriptive statistics for the conference characteristics and control variables. The mean (median) conference size is 82 (61) presentations, indicating that conferences generally involve a large number of presentations. ${ }^{11}$ Conferences also tend to be somewhat diverse in terms of industry membership, with a mean (median) industry size of $9(8)$ industries represented. The median firm has presented at one other conference in the prior 90 days. The mean DINFO_EVENT is 0.174 , indicating that only $17 \%$ of conference presentations

\footnotetext{
${ }^{11}$ There are 1,152 observations ( $1.2 \%$ of the sample) for which the conference size is only one presentation. While many of these are company-sponsored conferences, some may be conferences for which Thomson has not collected all of the participating firms. If we exclude these observations from the sample, the results are unchanged.
} 
are accompanied by material information disclosures in the form of earnings announcements (1.0\%), management forecasts $(2.9 \%)$, and/or Form 8-K filings $(15.0 \%)$ in the three-day window around the presentation. ${ }^{12}$ The sample firms tend to be large US firms with high institutional ownership $($ median $=67 \%)$, high analyst following (median $=9$ analysts $)$, and positive marketadjusted returns in the prior year $($ median $=1.5 \%)$. Conference presenters also tend to be growth firms with higher intangibles, lower leverage, lower return volatility, and higher beta. ${ }^{13}$

\section{Market Reactions to Conference Presentations}

We examine the market reaction to conference presentations using the three-day trading window $(-1,+1)$ around the date of the presentation. We use a three-day window because $43 \%$ of conferences are multiple-day events and one-third of the presentations occur outside of the Eastern US time zone. Thus, information relevant to the firm could be priced on the day before or after the actual presentation.

We measure the information content of the presentation with abnormal price variability and share turnover because we cannot measure the market's expectations before the presentation or whether the presentation is good or bad news (Beaver [1968], Frankel, et al. [1999], Landsman and Maydew [2002], Cready and Hurtt [2002]). We compute the abnormal absolute value of size-adjusted returns $\left(A B S \_S A R\right)$ as the difference between three-day absolute sizeadjusted returns and the mean three-day absolute size-adjusted returns in an estimation period, divided by the standard deviation of the mean absolute size-adjusted returns in the estimation period (Cready and Hurtt [2002]). We measure abnormal share turnover $\left(A B N \_T U R N\right)$ as three-

\footnotetext{
${ }^{12}$ We also measured DINFO_EVENT using a five-day window; about $25 \%$ of presentations had an earnings announcement, forecast, or 8-K filing within this window. All of our results were identical with this longer window. ${ }^{13} \mathrm{We}$ compared our sample to a sample of firms that did not present at conferences. In both univariate comparisons and a logistic regression, all of the firm characteristics in Table 2 except $E P$ and $C N I$ were significantly different between the two samples.
} 
day volume divided by shares outstanding, less the average three-day turnover in the estimation period. ${ }^{14}$ While correlated, the two measures differ based on the ex ante consensus among investors and ex post differences in interpretations (Kandel and Pearson [1995], Verrecchia [2001]). Because we cannot measure ex ante or ex post beliefs in this setting, we use both measures to assess information content (Cready and Hurtt [2002]).

Table 3 reports mean and median market reactions around the presentation. There is a significant spike in $A B S \_S A R$ and $A B N \_T U R N$ during the presentation window, as well as significantly positive levels in the three days prior to the presentation. The mean ABS_SAR $\left(A B N \_T U R N\right)$ of $0.076(0.148)$ during the conference window represents a $9 \%(5 \%)$ increase over the estimation period absolute returns (turnover). ${ }^{15}$ The small magnitude of these mean effects is not surprising given that managers generally do not disclose new information; rather, the information content stems from the private information of the audience. The median $A B S \_S A R$ and $A B N \_T U R N$ are negative because only $40-45 \%$ of the firms experience positive abnormal returns and turnover, suggesting that there is significant cross-sectional variation in the information content. Moreover, the correlation between $A B S \_S A R$ and $A B N \_T U R N$ in the threeday window is 0.36 , suggesting that some presentations produce price movements without high volume and vice versa. These univariate results motivate our examination of the disclosure milieu to understand the cross-sectional differences in information content. ${ }^{16}$

\footnotetext{
${ }^{14}$ Prior work finds that $A B S \_S A R$ is more powerful than the Beaver [1968] U-statistic (which is based on squared returns) in detecting unsigned price responses (Cready and Mynatt [1991], Subramaniam [1997]). Nevertheless, we find similar results using the Patell [1976] U-statistic and a standardized abnormal turnover measure.

${ }^{15}$ While the standardized $A B S \_S A R$ measure has better econometric properties than unadjusted absolute sizeadjusted returns (ASAR) (e.g., it adjusts for the normal level of ASAR and exhibits less skewness), it is harder to interpret. The mean ASAR during the conference window is 3.5\%, compared to 3.2\% during the estimation period with a standard deviation of $4.1 \%$. Multiplying ABS_SAR by $4.1 \%$ gives an approximation of the incremental ASAR. ${ }^{16} \mathrm{We}$ also looked at the signed size-adjusted returns $(S A R)$ during the three-day window. The mean (median) SAR is $0.50 \%(0.15 \%)$; both are significantly greater than zero. Francis, et al. [1997] finds a similar magnitude of mean market-model abnormal returns in the three-days around analyst presentations $(0.48 \%)$. The small positive $S A R$ suggests that managers are on average disclosing good news, the market is correcting an undervaluation, and/or
} 
Table 4 presents regressions of $A B S \_S A R$ and $A B N \_T U R N$ during the presentation window on the set of conference characteristics and the control variables. We include year and industry fixed effects; thus, the coefficients on the conference characteristics reflect incremental effects beyond the positive industry-year effects of the omitted group (other capital market conferences in other US cities). Significance tests are two-tailed and based on two-way clustered standard errors, with clustering at the firm and conference level and bootstrapping using the jackknife method (Cameron, Gelbach, and Miller [2006], Petersen [2009]).

Table 4 shows that the disclosure milieu significantly explains cross-sectional differences in abnormal absolute returns and share turnover, even after controlling for the significant effects of new information releases (DINFO_EVENT) and firm characteristics such as size, visibility, recent performance, and risk. Product market (DPRODMKT) and top brokerage firm conferences (DCAPMKT_TOP) have significantly greater absolute returns and share turnover than other capital market conferences, suggesting that the size and nature of the audience affect the information content either through the pool of potential private information or, in the case of product conferences, incentives to release new information. Conference location also significantly affects the market reaction, as presentations at money centers (DMONCEN) and destinations (DDEST) exhibit significantly larger information content than conferences in other US cities and outside the US (DNONUS). This finding is consistent with the market response being impacted by both the composition of the audience and degree of interactions among audience and presenters. There are also significantly greater market responses to presentations at larger conferences (LCONFSIZE), consistent with these conferences attracting a larger set of investors and increasing the informedness of the presentation. Each significant coefficient

there is upward price pressure due to attracting more investors. The only conference characteristics that significantly increase $S A R$ are product market conferences and conference size. The product market result is consistent with managers using this venue to provide new product announcements. 
represents $5-10 \%$ greater abnormal absolute size-adjusted returns and share turnover than in the omitted group. For example, a presentation at a product market conference in a money center would produce, on average, a $3.8 \%$ absolute $S A R$, compared to $3.2 \%$ for a presentation at a small brokerage firm conference in a regional US city (an increase of 19\%). ${ }^{17}$

Table 4 also shows a larger absolute return response to presentations at industry-focused conferences (DINDUS_CONF), consistent with greater information transfers among presenting firms. There is a significantly lower absolute return response to presentations by firms that have recently presented in other conferences (LPRIORPRES), consistent with a reduction in the potential private information of investors due to the prior presentations. In both cases, there is no significant effect on abnormal turnover. This finding suggests that industry expertise and prior presentations create greater ex ante consensus among investors about the firm and a lesser degree of ex post differences in interpretations, resulting in any new information affecting price without a significantly higher amount of individual trades. Overall, we find that conference sponsor, location, size, and industry-focus are significantly associated with the market reaction to conference presentations. This evidence indicates that the disclosure milieu influences the degree to which participants are able to revise their beliefs about the firm. ${ }^{18}$

\section{Changes in Investor and Analyst Following after Presentations}

We examine changes in institutional investor and analyst following after conference presentations over two horizons. First, we report two-quarter changes in analyst following

\footnotetext{
${ }^{17}$ To put this magnitude in perspective, we computed absolute $S A R$ for earnings announcements, forecasts, and Form 8-K filings during the same quarter as a presentation for our sample firms. The average three-day absolute SAR is $6.4 \%$ for forecasts, $5.9 \%$ for earnings announcements, and $4.2 \%$ for Form 8 -K filings.

${ }^{18}$ The identity of the presenter (e.g., CEO, CFO) is a possible correlated omitted variable in this setting, but is only available for about $10 \%$ of the presentations that have archived transcripts. We examined the transcript subsample to test whether CEO attendance affected the market reaction. Before including a CEO indicator, we found that some conference characteristics were no longer significant at conventional levels due to the small sample size. However, adding a CEO indicator variable did not affect the signs or significance of any of the conference characteristics.
} 
(CNANL2) and institutional investor ownership (CPIH2). CNANL2 is the difference between the number of unique analysts issuing forecasts in the first full calendar quarter after the presentation and the number in the calendar quarter prior to the presentation. ${ }^{19} \mathrm{CPIH} 2$ is the difference between institutional ownership at the end of the calendar quarter subsequent to the presentation and the end of the quarter prior to the presentation. We do not examine the calendar quarter of the presentation because the presentation could have taken place too late in the quarter for investors and analysts to react. Second, we report four-quarter changes in analyst following (CNANL4) and institutional investor ownership (CPIH4) as the difference between analyst following and institutional ownership three full quarters after the presentation and the quarter prior to the presentation (i.e., the same calendar quarters one year apart). The advantage of the two-quarter change is that it more closely ties the change in analyst and investor following to the presentation. The disadvantage of the two-quarter change is that there is seasonality in analyst forecasting behavior (e.g., more forecasts are generally issued prior to the annual earnings) and an increase in following may not be detected in a short window.

Table 5 provides univariate evidence showing that firms presenting at conferences experience significant increases in both analyst following and institutional ownership, on average, subsequent to the presentations. The mean CNANL2 (CNANL4) is $0.201(0.326)$ and the median changes are zero. These changes reflect that fact that only $40-45 \%$ of firms experience increases in analyst coverage after a presentation, and those that do tend to have an increase of one analyst. The magnitude of the mean increase in CNANL4 is comparable to prior work, which typically finds a mean change in analyst following of less than one analyst after an

\footnotetext{
${ }^{19}$ We estimated all of our results using both logged and unlogged changes in analyst following. There is some skewness in the level of analyst following, so we use the log of analyst following as a control variable in the tables. However, because the skewness is less pronounced in unlogged changes in analyst following and the logged changes are more difficult to interpret, we report the unlogged changes in the tables. The signs and significance of all of the main results are the same for logged and unlogged changes in analyst following.
} 
event (e.g., Healy, et al. [1999], Irani and Karamanou [2003]). Francis, et al. [1997] reports a mean annual increase of 0.77 in analyst coverage after presentations at conferences solely focused on analysts. Given that many conferences are not geared toward attracting analysts (e.g., product market), and many exclude outside analysts (e.g., top brokerage), increases in analyst coverage should not be broadly realized in our sample.

Table 5 shows a mean (median) $\mathrm{CPIH} 2$ of 0.017 (0.01) and a mean (median) CPIH4 of $0.028(0.02)$, with around $60 \%$ of firms experiencing increases in institutional investor ownership. These changes are also comparable to prior work, e.g., Bushee and Noe [2000] find an increase of 0.011 in percent transient institutional ownership for firms increasing disclosure quality and Covrig, DeFond and Hung [2007] find firms that adopt International Accounting Standards have 0.009 higher percentage of foreign institutional ownership.

Table 6 presents results of regressions of two- and four-quarter changes in institutional ownership and analyst following on the set of conference characteristics and control variables. In addition, we control for the information content of the presentation using the variables in Table 3 (ABS_SAR and $\left.A B N \_T U R N\right)$, as well as signed size-adjusted returns (SAR) to capture any potential effects due to the direction of the return reaction to the presentation. We include year and industry fixed effects; thus, the coefficients on the conference characteristics reflect incremental effects beyond the positive industry-year effects of the omitted group (other capital market conferences in other US cities). Significance tests are two-tailed and based on two-way clustered standard errors, with clustering at the firm and conference level and bootstrapping using the jackknife method (Cameron, Gelbach, and Miller [2006], Petersen [2009]).

Table 6 shows that most of the control variables significantly explain changes in analyst and institutional investor following. Notably, the measures of the three-day market reaction to 
the presentation—ABS_SAR, $A B N \_T U R N$, and $S A R$ —all significantly explain future changes in analyst and investor following. Thus, the results for the conference characteristics can be interpreted as measuring the effect of the audience and its interactions incremental to the information content of the presentation, i.e. the effect of the milieu on participants' ability to assess the competence and credibility of managers, as well as their commitment to transparency.

The first two columns of Table 6 show that changes in analyst following are negatively associated with presentations at product market conferences and top brokerage conferences, consistent with analysts not being the target audience in either of these settings. These negative relations still reflect increases in analyst following, but they are 7-12\% smaller increases than mean CNANL4 of 0.983 for the omitted group of other capital market conferences (which include analyst societies). Analysts are also significantly less likely to increase coverage of firms presenting at non-US conferences, consistent with US analysts not being the target of those presentations. There is no significant relation between conference size and analyst following, suggesting either that the pool of potential new analysts does not increase with the number of firms presenting or that larger conferences are larger due to more small firms, for which analysts are less likely to initiate coverage. Changes in analyst following are significantly positively related to presentations at industry-focused conferences, but only using the seasonally-adjusted CNANL4, consistent with the industry-based structure of analyst coverage. Finally, increases in analyst following are significantly larger for firms that have presented at multiple recent conferences, consistent with analysts initiating coverage of firms that have become more visible and, hence, provide a bigger potential demand for analyst research and brokerage services.

Similar to analysts, the change in institutional ownership is positively associated with the number of recent conference presentations, suggesting that frequent presentations reach a greater 
potential audience of new investors, and negatively associated with non-US conferences. Also similar to analysts, and contrary to our predictions, there is no relation between destination or money center conferences and institutional ownership, indicating that the increases in following for these conferences are similar to the omitted group (other capital market conferences in other US cities). In contrast, changes in institutional ownership are positively related to presentations at large conferences and top brokerage firm conferences, with the latter resulting in $0.5 \%$ higher CPIH4 than other capital market conferences. These results suggest that institutional investors are more likely to attend conferences that provide them with preferential access to a large number of firms, thus reducing the costs of learning about these firms.

Overall, the disclosure milieu has a significant effect on changes in analyst and investor following incremental to the information content of the presentations. Notably, top brokerage and larger conferences attract greater institutional ownership, but not greater analyst following, consistent with these conferences providing a larger pool of potential investors, but not necessarily a larger pool of potential new analysts. These findings indicate that the milieu captures audience effects per se, rather than a general relation between conferences and visibility that affect all market participants in the same manner. ${ }^{20}$

\section{Conclusion}

We examine a large sample of conference presentations to investigate how the setting in which a disclosure takes place — the "disclosure milieu"-affects the market reaction to

\footnotetext{
${ }^{20}$ Our results could be subject to an endogeneity bias due to managers choosing to present at certain conferences; however, we believe selection issues are likely to be limited in our sample. First, firms tend not to always select the same bundle of conference characteristics (e.g., the average firm presenting at four conferences in a year experiences two different types of sponsors and locations). Second, we estimated a Heckman two-stage model based on the decision to present at any conference in a given year (using the variables in Table 2) and found that none of our main results in Table 4 and 6 lose statistical significance when we include the inverse Mills ratio.
} 
disclosure. There are significant mean abnormal stock return and volume reactions to presentations, driven by the $40-45 \%$ of the firms experiencing a positive abnormal market response. However, there is a great deal of cross-sectional variation as indicated by the negative median reactions. We find that conference characteristics such as sponsor, location, size, and industry-focus are significantly associated with the market response, consistent with the disclosure milieu explaining the cross-sectional variation in the information content of the presentation. We also find that conference characteristics are associated with changes in analyst following and institutional investor ownership. Analysts increase their following in firms with frequent recent presentations at industry-focused and capital market conferences, consistent with analysts seeking firms that are building visibility through conference activity. In contrast, large conferences hosted by the top brokerage firms are associated with increases in institutional ownership, consistent with these conferences attracting a larger pool of prospective investors for the firm.

These findings contribute to the voluntary disclosure literature by documenting how the “disclosure milieu," or physical and social space in which a disclosure occurs, influences the market response to disclosure by affecting the nature of the audience and its interactions. While the conference setting allows researchers to empirically measure the characteristics of the milieu, the disclosure milieu likely affects managers and investors in other disclosure settings that involve a defined physical place, a specific time, and/or a limited audience (e.g., road shows or annual shareholder meetings). For example, critics have objected to proposals for "virtual" annual meetings based on concerns about not being able to observe other audience members and losing the interaction with managers. Our findings suggest that, despite advances in technology, virtual meetings are unlikely to serve as a sufficient substitute for face-to-face meetings due to 
the economically significant effect of the disclosure milieu on investors' information gathering and belief revision. Thus, future research examining the disclosure milieu could provide new insights into not only the market response to voluntary disclosure, but also the choice of voluntary disclosure venues. 


\section{References}

Andersen, P. "Nonverbal Communication: Forms and Functions." Long Grove, IL: Waveland Press, 2008.

Beaver, W. "The Information Content of Annual Earnings Announcements." Journal of Accounting Research (1968): 67-92.

Bowen, R., A. Davis, and D. Matsumoto. "Do Conference Calls Affect Analysts' Forecasts?" The Accounting Review 77 (2002): 285-316.

Bradshaw, M., B. Bushee, and G. Miller. "Accounting Choice, Home Bias, and U.S. Investment in Non-U.S. Firms.” Journal of Accounting Research 42 (2004): 795-841.

Brennan, M., A. Wang, and Y. Xia. "Estimation and Test of a Simple Model of Intertemporal Capital Asset Pricing." The Journal of Finance 59 (2004): 1743-75.

Bushee, B., D. Matsumoto, and G. Miller. "Open versus Closed Conference Calls: The Determinants and Effects of Broadening Access to Disclosure." Journal of Accounting and Economics 34 (2003): 149-80.

Bushee, B., D. Matsumoto, and G. Miller. "Managerial and Investor Responses to Disclosure Regulation: The Case of Reg FD and Conference Calls." The Accounting Review 79 (2004): $\underline{617-43 .}$

Bushee, B., and G. Miller. "Investor Relations, Firm Visibility and Investor Following." The Accounting Review (Forthcoming).

Bushee, B., M. Jung, and G. Miller. "Do Investors Benefit from Selective Access to Management?" Working paper, Wharton School, 2011.

Bushee, B., and C. Noe. "Corporate Disclosure Practices, Institutional Investors, and Stock Return Volatility.” Journal of Accounting Research 38 (2000): 171-202.

Cooley Godward LLP. "SEC Regulation FD: New Rules for Communicating With Analysts and Investors." News from the Public Companies practice group. (October 2000).

Cameron, A., J. Gelbach, and D. Miller. "Robust Inference with Multi-way Clustering" NBER Technical Working Paper No. 327 (2006).

Covrig, V., M. DeFond, and M. Hung. "Home Bias, Foreign Mutual Fund Holdings, and the Voluntary Adoption of International Accounting Standards." Journal of Accounting Research 45 (2007): 41-70. 
Cready, W. and D. Hurtt. "Assessing Investor Response to Information Events Using Return and Volume Metrics.” Accounting Review 77 (2002): 891-909.

Cready, W. and P. Mynatt. "The Information Content of Annual Reports: A Price and Trading Response Analysis.” Accounting Review 66 (1991): 291-312.

Dow Jones Newswires. "Fair Disclosure Takes Anticipation Out Of Conferences" (February 23, 2001).

Francis, J., J.D. Hanna, and D. Philbrick. "Management Communications with Securities Analysts." Journal of Accounting and Economics 24 (1997): 363-94.

Frankel, R., M. Johnson, and D. Skinner. "An Empirical Examination of Conference Calls as a Voluntary Disclosure Medium.” Journal of Accounting Research 37 (1999): 133-50.

Greenwich Associates. "U.S. Equity Research: Bulge Bracket Down, But Not Out.” Greenwich Report (June 2010).

Healy, P., A. Hutton, and K. Palepu. "Stock Performance and Intermediation Changes Surrounding Sustained Increases in Disclosure." Contemporary Accounting Research 16 (1999): 485-520.

Holthausen, R. and R. Verrecchia. "The Effect of Informedness and Consensus on Price and Volume Behavior." The Accounting Review 65 (1990): 191-208.

Hutton, A., G. Miller, and D. Skinner. "The Role of Supplementary Statements with Management Earnings Forecasts." Journal of Accounting Research 41 (2003): 867-90.

Indjejikian, R. "The Impact of Costly Information Interpretation on Firm Disclosure Decisions." Journal of Accounting Research 29 (1991): 277-301.

Irani, A., and I. Karamanou. "Regulation Fair Disclosure, Analysts Following, and Analyst Forecast Dispersion.” Accounting Horizons 17 (2003): 15-29.

Jackson, H. “Friendly Persuasion.” Institutional Investor 41 (2007): 47-53.

Kim, O., and R. Verrecchia. "Market Liquidity and Volume Around Earnings Announcements." Journal of Accounting and Economics 17 (1994): 41-67.

Kandel, E., and N. Pearson. "Differential Interpretation of Public Signals and Trade in Speculative Markets.” The Journal of Political Economy 103 (1995): 831-872.

Landsman, W., and E. Maydew. "Has the Information Content of Quarterly Earnings Announcements Declined in the Past Three Decades?" Journal of Accounting Research 40 (2002): 797-808. 
Lang, M., and R. Lundholm. "Corporate Disclosure Policy and Analyst Behavior." The Accounting Review 71 (1996a): 467-92.

Lang, M., and R. Lundholm. "The Relation Between Security Returns, Firm Earnings and Industry Earnings.” Contemporary Accounting Research 13 (1996b): 607-29.

Lev, B., and S. Penman. "Voluntary Forecast Disclosures, Nondisclosure, and Stock Prices." Journal of Accounting Research 28 (1990): 49-76.

Mayew, W. "Evidence of Management Discrimination Among Analysts During Earnings Conference Calls." Journal of Accounting Research 46 (2008): 627-659.

Mayew, W. and M. Venkatachalam. "The Power of Voice: Managerial Affective States and Future Firm Performance.” Journal of Finance (Forthcoming).

Mehrabian, A. "Non Verbal Communication.” New Brunswick, NJ: Aldine Transaction Publishing, 1972.

Morris, S. and H. Shin. "Global Games: Theory and Applications." Advances in Economics and Econometrics, the Eighth World Congress (edited by M. Dewatripont, L. Hansen and S. Turnovsky), Cambridge University Press, 2003.

Patell, J. "Corporate Forecasts of Earnings Per Share and Stock Price Behavior: Empirical Tests." Journal of Accounting Research 14 (1976): 246-76.

Petersen, M. "Estimating Standard Errors in Finance Panel Data Sets: Comparing Approaches." The Review of Financial Studies 22 (2009): 435-480.

Rodier, M. "Wall Street Firms, Hedge Funds, Recruit CIA, Ex-Military Intelligence." Wall Street Technology (2010). Accessed online at http://www.wallstreetandtech.com/financial-riskmanagement/showArticle.jhtml?articleID $=222700382$

SEC v. Siebel Systems, et al., United States District Court for the Southern District of New York, Memorandum Decision and Order, August 31, 2005.

Skinner, D. "Why Firms Voluntarily Disclose Bad News." Journal of Accounting Research 32 (1994): 38-60.

Subramaniam, C. "Detecting Information Content of Corporate Announcements Using Variance Increases: A Methodological Study." Journal of Accounting, Auditing, and Finance (1997): 415-430.

Verrecchia, R. “Essays on disclosure." Journal of Accounting and Economics 32 (2001): 97-180. 


\section{APPENDIX \\ Conference Examples and Classifications by Sponsor and by Location}

Panel A: Conferences taking place on October 3, 2007

\begin{tabular}{|c|c|c|}
\hline Conference Name & Dates & Location \\
\hline Banc of America Securities Debt Capital Markets Seminar & Oct 3-4 & New York, NY \\
\hline Bear, Stearns \& Co. Inc. Lisbon CDO Conference & Oct 3 & Lisbon, PRT \\
\hline BioContact Biopharmaceutical Partnership Symposium & Oct 3-5 & Quebec, CAN \\
\hline BioProcess International ${ }^{\mathrm{TM}}$ Conference \& Exhibition & Oct 1-4 & Boston, MA \\
\hline Borsa Italia Star Conference & Oct 3-4 & London, GB \\
\hline Consumer Analyst Group of New York Monthly Meeting & Oct 3 & New York, NY \\
\hline CEATEC JAPAN 2007 & Oct $1-5$ & Chiba, JAP \\
\hline CFO.com Rising West Conference & Sep 30-Oct 3 & Las Vegas, NV \\
\hline CIBC World Markets 2nd Annual Industrials Confere & Oct 2-3 & New York, NY \\
\hline Credit Suisse Aerospace and Defence Conference & Oct 3 & London, GB \\
\hline Deutsche Bank Securities Inc. Leveraged Finance Conference & Oct 2-4 & Scottsdale, AZ \\
\hline Deutsche Bank Strategy \& Solutions Derivatives Conference & Oct 3-5 & Hong Kong, CHN \\
\hline EEI Occupational Safety and Health Committee Conference & Sep 30-Oct 3 & Tucson, AZ \\
\hline EEI Fall National Accounts Workshop & Sep 30-Oct 3 & Indianapolis, IN \\
\hline Gabelli \& Company, Inc. 3rd Annual RFID Conference & Oct 3 & Chicago, IL \\
\hline Global CDO and Credit Opportunity Fund Conference & Oct 2-5 & Phoenix, AZ \\
\hline IBC BioProcess Con & Oct $1-4$ & , MA \\
\hline IEEE 2007 International Telecommunic & Sep 30-Oct 4 & ITA \\
\hline Independent Petroleum Ass & Oct $1-3$ & San Francisco, C \\
\hline IQPC Hedge Fun & Oct $1-3$ & Stamford, CT \\
\hline Leerink Swann \& Company: Aesthetics Roundtable Conference & Oct 3 & New York, NY \\
\hline Marcus Evans Lean and Six Sigma for Defense Conference & Oct 3-5 & Arlington, VA \\
\hline Opal Financial Group Private Equity Summit & Oct $1-3$ & Las Vegas, NV \\
\hline RailTrends 2007 Conference & Oct 3-4 & New York, NY \\
\hline Reed $\mathrm{H}$ & Oct & Osaka, JAP \\
\hline Biotech in Europe Investor Forum & Oct $2-3$ & Zur \\
\hline Sibos 2007 Boston & Oct $1-5$ & Boston, MA \\
\hline Society for Information Display Mobil & Oct 2-3 & San Diego, CA \\
\hline Strategic Research Inst. 4th Annual Energy Tech Conference & Oct 3-4 & San Jose, CA \\
\hline The 2007 Private Equity Energy Forum & Oct 2-3 & New York, NY \\
\hline UBS Climate Change - Impact and Opportunities Conference & Oct 3 & London, GB \\
\hline Webcom Software Business 2007 Conference & Oct 2-3 & Santa Clara, CA \\
\hline William Blair \& Company Micro-/ Small-Cap Growth Conferer & Oct 3 & New York, NY \\
\hline Windhover Information In3 East Conference & Oct 3-5 & Boston, MA \\
\hline
\end{tabular}

Panel A presents the list of conferences taking place on October 3, 2007 according to Thomson Financial Street Events. 
APPENDIX (Continued)

Conference Examples and Classifications by Sponsor and by Location

Panel B: Classification of Conference Sponsors

\begin{tabular}{lrrrrrr} 
& \multicolumn{2}{c}{$\begin{array}{c}\text { Number of } \\
\text { Organizations }\end{array}$} & \multicolumn{2}{c}{$\begin{array}{c}\text { Number of } \\
\text { Conferences }\end{array}$} & \multicolumn{2}{c}{$\begin{array}{c}\text { Number of } \\
\text { Presentations }\end{array}$} \\
\hline Product Market Sponsors & 269 & $(31.7 \%)$ & 662 & $(12.1 \%)$ & 7,056 & $(7.4 \%)$ \\
Trade Association & 198 & $(23.3 \%)$ & 514 & $(9.4 \%)$ & 2,029 & $(2.1 \%)$ \\
Consulting Firm & 68 & $(8.0 \%)$ & 243 & $(4.4 \%)$ & 1,044 & $(1.1 \%)$ \\
Media Organization & 57 & $(6.7 \%)$ & 71 & $(1.3 \%)$ & 166 & $(0.2 \%)$ \\
Individual Company & 6 & $(0.7 \%)$ & 9 & $(0.2 \%)$ & 61 & $(0.1 \%)$ \\
$\quad$ University & 14 & $(1.6 \%)$ & 1,943 & $(35.6 \%)$ & 43,867 & $(46.1 \%)$ \\
Capital Market Sponsors & 191 & $(22.5 \%)$ & 1,614 & $(29.5 \%)$ & 37,091 & $(39.0 \%)$ \\
$\quad$ Top Brokerage Firm & 13 & $(1.5 \%)$ & 159 & $(2.9 \%)$ & 1,777 & $(1.9 \%)$ \\
Other Brokerage Firm & 25 & $(2.9 \%)$ & 183 & $(3.3 \%)$ & 1,435 & $(1.5 \%)$ \\
Analyst Society & $\underline{8}$ & $(0.9 \%)$ & $\underline{66}$ & $(1.2 \%)$ & $\underline{579}$ & $(0.6 \%)$ \\
Investor Relations Firm & 849 & & 5,464 & & 95,105 & \\
$\quad$ Stock Exchange & & & & & & \\
Total & & & & & & \\
\hline
\end{tabular}

Panel B shows the breakdown of conference sponsors by the number of unique organizations in the category, the number of conferences hosted by the category, and the numbers of presentations at such conferences, which is the sample used in the empirical tests. For each conference, we first identify the sponsoring organization from the title of the conference or from Internet searches. Next, we classify the sponsor into one of ten categories based on our prior knowledge of the sponsor and on Internet searches for information about the sponsors. Trade associations include research associations (e.g., American Academy of Allergy, Asthma and Immunology) and industry associations (e.g., American Bankers Association). Consulting firms include general management consulting firms (e.g., Accenture), industry-specific consulting firms (e.g., Cambridge Energy Research Associates), and organizations that specialize in trade fairs (e.g., Reed Exhibitions). Media organizations include general media outlets (e.g. Economist) and industry-focused publications (e.g., Chemical Week). Individual companies include any company whose business is not consulting or media that hosts a conference (e.g., Ford Motor Company Convergence Conference). Finally, a small number of universities host conferences. Brokerage firms include firms that provide brokerage and/or investment research services. Due to the wide range of size and prestige within this group, we subdivided it into "top" brokerage firms and other brokerage firms based on the number of conferences hosted per year in our sample. There are 14 "top" brokerage firms that have hosted more than 12 conferences per year (or one per month), on average, while all other brokerages have hosted fewer than nine per year. Analyst societies include the New York Society of Security Analysts and other regional analyst groups. Investor Relations firms are firms whose main business is to target investors for their clients' stock, and stock exchanges include the NYSE, Borsa Italia, and other exchanges. 
APPENDIX (Continued)

Conference Examples and Classifications by Sponsor and by Location

Panel C: Classification of Conference Locations

\begin{tabular}{lrrrr} 
& \multicolumn{2}{c}{$\begin{array}{c}\text { Number of } \\
\text { Conferences }\end{array}$} & \multicolumn{2}{c}{$\begin{array}{c}\text { Number of } \\
\text { Presentations }\end{array}$} \\
\hline Money Centers & & & & \\
\hline New York City & 2,012 & $(36.8 \%)$ & 42,436 & $(44.6 \%)$ \\
San Francisco & 385 & $(7.0 \%)$ & 9,786 & $(10.3 \%)$ \\
Boston & 337 & $(6.2 \%)$ & 6,229 & $(6.5 \%)$ \\
Chicago & 132 & $(2.4 \%)$ & 2,936 & $(3.1 \%)$ \\
Destinations & & & & \\
Florida & 255 & $(4.7 \%)$ & 6,397 & $(6.7 \%)$ \\
California & 266 & $(4.9 \%)$ & 6,047 & $(6.4 \%)$ \\
Arizona & 101 & $(1.8 \%)$ & 3,000 & $(3.2 \%)$ \\
Nevada & 167 & $(3.1 \%)$ & 2,960 & $(3.1 \%)$ \\
Other & 79 & $(1.4 \%)$ & 2,004 & $(2.1 \%)$ \\
Other US & & & & \\
Maryland \& DC & 97 & $(1.8 \%)$ & 1,504 & $(1.6 \%)$ \\
Georgia & 52 & $(1.0 \%)$ & 1,160 & $(1.2 \%)$ \\
Texas & 108 & $(2.0 \%)$ & 900 & $(0.9 \%)$ \\
Other & 488 & $(8.9 \%)$ & 4,217 & $(4.4 \%)$ \\
Non-US & & & & \\
United Kingdom & 336 & $(6.1 \%)$ & 2,133 & $(2.2 \%)$ \\
Other Europe & 234 & $(4.3 \%)$ & 1,671 & $(1.8 \%)$ \\
Canada & 236 & $(4.3 \%)$ & 1,178 & $(1.2 \%)$ \\
Asia & 157 & $(2.9 \%)$ & 505 & $(0.5 \%)$ \\
Other & 22 & $(0.4 \%)$ & 42 & $(0.0 \%)$ \\
Total & 5,464 & & 95,105 & \\
\hline
\end{tabular}

Panel C shows the breakdown of the conference location by the number of conferences hosted and by the numbers of presentations at such conferences in our sample. We collected the location of the conference from the Thomson Street Events database. Money Center conferences are those held in the New York City, San Francisco, Boston, and Chicago metro areas. We classify Destination conferences as those held in locations that would generally be considered vacation destinations, including Florida, Southern California, Arizona, Nevada, any other obvious resort destinations (e.g., Jackson Hole, Myrtle Beach, Caribbean islands). The authors independently attempted to classify locations as destinations, and the overlap among our ratings was over 90\%. All other conferences held in the US are classified as "Other US." Finally, all conferences held outside of the US, other than those in Caribbean islands, were classified as "non-US". We note that two difficult cities to classify were Los Angeles and New Orleans. As the second-largest city, Los Angeles could be considered a money center. However, very few conferences in the Los Angeles metro area are held in Los Angeles itself. Almost all are held in Orange County ocean-side communities or in Anaheim. We classified New Orleans in the "other US" city category, rather than a destination location, because the majority of the New Orleans conferences were hosted by local brokerages or focused on local industries (e.g., Oil and Gas). We estimated our results with Los Angeles classified as a money center and New Orleans classified as a destination, and the results were similar. 
TABLE 1

Sample Composition

Panel A: Conference Sponsor and Location by Year

\begin{tabular}{cccc} 
& \multicolumn{3}{c}{ Sponsor } \\
\cline { 2 - 4 } & & \multicolumn{2}{c}{ Capital Market } \\
\cline { 3 - 4 } Year & $\begin{array}{c}\text { Product } \\
\text { Market }\end{array}$ & $\begin{array}{c}\text { Top } \\
\text { Brokerages }\end{array}$ & Other \\
\hline 1999 & 33 & 798 & 1,219 \\
2000 & 307 & 689 & 2,447 \\
2001 & 429 & 2,645 & 3,111 \\
2002 & 681 & 5,393 & 3,433 \\
2003 & 1,137 & 5,221 & 4,128 \\
2004 & 1,551 & 6,268 & 4,980 \\
2005 & 2,034 & 7,517 & 6,838 \\
2006 & 2,015 & 8,408 & 7,800 \\
2007 & $\underline{2,169}$ & $\underline{6,928}$ & $\underline{6,926}$ \\
Total & 10,356 & 43,867 & 40,882 \\
& $10.9 \%$ & $46.1 \%$ & $43.0 \%$ \\
\hline
\end{tabular}

\begin{tabular}{|c|c|c|c|c|}
\hline \multicolumn{4}{|c|}{ Location } & \multirow[b]{3}{*}{ Total } \\
\hline \multicolumn{3}{|c|}{ US } & \multirow[b]{2}{*}{ Non-US } & \\
\hline $\begin{array}{l}\text { Money } \\
\text { Centers }\end{array}$ & Destinations & Other US & & \\
\hline 1,147 & 448 & 434 & 21 & 2,050 \\
\hline 2,172 & 732 & 466 & 73 & 3,443 \\
\hline 4,270 & 908 & 698 & 309 & 6,185 \\
\hline 6,145 & 2,083 & 737 & 542 & 9,507 \\
\hline 7,021 & 2,181 & 858 & 426 & 10,486 \\
\hline 8,016 & 3,211 & 905 & 667 & 12,799 \\
\hline 10,379 & 3,681 & 1,308 & 1,021 & 16,389 \\
\hline 11,305 & 4,235 & 1,295 & 1,388 & 18,223 \\
\hline$\underline{10,932}$ & $\underline{2,929}$ & $\underline{1,080}$ & $\underline{1,082}$ & $\underline{16,023}$ \\
\hline 61,387 & 20,408 & 7,781 & 5,529 & 95,105 \\
\hline $64.5 \%$ & $21.5 \%$ & $8.2 \%$ & $5.8 \%$ & \\
\hline
\end{tabular}

Panel B: Conference Sponsor and Location by Industry Focus

\begin{tabular}{|c|c|c|c|c|c|c|c|c|}
\hline \multirow[b]{2}{*}{ Conference Focus } & \multirow[b]{2}{*}{$\begin{array}{l}\text { Product } \\
\text { Market }\end{array}$} & \multicolumn{2}{|c|}{ Capital Market } & \multicolumn{3}{|c|}{ US } & \multirow[b]{2}{*}{ Non-US } & \multirow[b]{2}{*}{ Total } \\
\hline & & $\begin{array}{c}\text { Top } \\
\text { Brokerages }\end{array}$ & Other & $\begin{array}{l}\text { Money } \\
\text { Centers }\end{array}$ & Destinations & Other US & & \\
\hline Industry-focused & 6,049 & 11,037 & 9,478 & 17,010 & 3,702 & 2,722 & 3,130 & 26,564 \\
\hline Broad & $\underline{4,307}$ & $\underline{32,830}$ & $\underline{31,404}$ & $\underline{44,377}$ & $\underline{16,706}$ & $\underline{5,059}$ & $\underline{2,399}$ & $\underline{68,541}$ \\
\hline Total & 10,356 & 43,867 & 40,882 & 61,387 & 20,408 & 7,781 & 5,529 & 95,105 \\
\hline
\end{tabular}


TABLE 1 (Continued)

Sample Composition

Panel C: Cross-Tabulation of Location and Sponsor

\begin{tabular}{|c|c|c|c|}
\hline \multirow[b]{3}{*}{ Location } & \multicolumn{3}{|c|}{ Sponsor } \\
\hline & \multirow[b]{2}{*}{$\begin{array}{l}\text { Product } \\
\text { Market }\end{array}$} & \multicolumn{2}{|c|}{ Capital Market } \\
\hline & & $\begin{array}{c}\text { Top } \\
\text { Brokerages }\end{array}$ & Other \\
\hline Destinations & 3,442 & 10,696 & 6,270 \\
\hline Money Centers & 4,366 & 28,737 & 28,284 \\
\hline Other US & 1,471 & 1,894 & 4,416 \\
\hline Non-US & $\underline{1,077}$ & $\underline{2,540}$ & $\underline{1,912}$ \\
\hline Total & 10,356 & $4 \overline{3,867}$ & $4 \overline{40,882}$ \\
\hline
\end{tabular}

Panel D: Fama-French Industries of Conference Presenters

\begin{tabular}{lrr} 
Industry & Frequency & Percent \\
\hline Personal and Business Services & 16,110 & 16.9 \\
Healthcare, Medical Equipment, Pharmaceutical Products & 16,062 & 16.9 \\
Business Equipment & 15,302 & 16.1 \\
Banking, Insurance, Real Estate, Trading & 12,077 & 12.7 \\
Petroleum and Natural Gas & 4,152 & 4.4 \\
Communication & 3,753 & 4.0 \\
Retail & 3,168 & 3.3 \\
Fabricated Products and Machinery & 2,639 & 2.8 \\
Wholesale & 2,567 & 2.7 \\
Utilities & 2,144 & 2.3 \\
Transportation & 1,800 & 1.9 \\
Construction and Construction Materials & 1,666 & 1.8 \\
Electrical Equipment & 1,590 & 1.7 \\
Recreation & 1,456 & 1.5 \\
Chemicals & 1,447 & 1.5 \\
Restaurants, Hotels, Motels & 1,343 & 1.4 \\
All Other Industries Less than 1\% of the sample & $\underline{7,829}$ & $\underline{8.3}$ \\
Total & 95,105 & 100 \\
\hline
\end{tabular}

Table 1 provides a breakdown of conference presentations by sponsor, location, year, type, and Fama-French industries. "Product Market" conferences focus on communications with business partners and "Capital Market" conferences involve interactions with investors and analysts. Within Capital Market conferences, those sponsored by brokerage firms hosting more than 12 conferences per year are categorized as "Top Brokerages" and the others are under "Other", which includes all other brokerage firms, analyst societies, investor relations firms, and stock exchanges. Conferences located in "Money Centers" are those held in New York City, San Francisco, Boston, and Chicago metro areas. "Destination" conferences are held in Florida, Southern California, Arizona, Nevada and other resort destinations. Conferences held in other U.S. locations are categorized as "Other US" and those held outside of the U.S. are categorized as "Non-US" (see Appendix for more details). Panel A shows the sponsors and locations of the presentations by calendar year. Panel B presents the number of industry-focused conferences and their distribution across sponsors and locations. We define an industry-focused conference as having fewer than four Fama-French 30 industries (from Kenneth French's website) represented at the conference. Panel C presents a crosstabulation of conferences by location and sponsor. Panel D presents a breakdown by Fama-French industries. 
TABLE 2

Descriptive Statistics of Conference and Firm Characteristics

\begin{tabular}{lrrrrrrr}
\hline & Mean & Std. Dev & Min & P25 & Median & P75 & Max \\
Variable & 0.109 & 0.312 & 0.000 & 0.000 & 0.000 & 0.000 & 1.000 \\
\hline DPRODMKT & 0.461 & 0.498 & 0.000 & 0.000 & 0.000 & 1.000 & 1.000 \\
DCAPMKT_TOP & 0.645 & 0.478 & 0.000 & 0.000 & 1.000 & 1.000 & 1.000 \\
DMONCEN & 0.215 & 0.411 & 0.000 & 0.000 & 0.000 & 0.000 & 1.000 \\
DDEST & 0.058 & 0.234 & 0.000 & 0.000 & 0.000 & 0.000 & 1.000 \\
DNONUS & 8.662 & 5.872 & 1.000 & 4.000 & 8.000 & 12.000 & 26.000 \\
NINDUS & 0.279 & 0.449 & 0.000 & 0.000 & 0.000 & 1.000 & 1.000 \\
DINDUS_CONF & 82.118 & 71.735 & 1.000 & 27.000 & 61.000 & 119.000 & 377.000 \\
CONFSIZE & 3.934 & 1.131 & 0.000 & 3.296 & 4.111 & 4.779 & 5.932 \\
LCONFSIZE & 1.466 & 1.618 & 0.000 & 0.000 & 1.000 & 2.000 & 16.000 \\
PRIORPRES & 0.713 & 0.610 & 0.000 & 0.000 & 0.693 & 1.099 & 2.833 \\
LPRIORPRES & & & & & & & \\
DINFO_EVENT & 0.174 & 0.379 & 0.000 & 0.000 & 0.000 & 0.000 & 1.000 \\
MV & $7,942.889$ & $24,465.530$ & 2.456 & 431.550 & $1,336.940$ & $4,782.233$ & $498,203.100$ \\
LMV & 7.330 & 1.769 & 0.898 & 6.067 & 7.198 & 8.473 & 13.119 \\
PIH & 0.619 & 0.272 & 0.000 & 0.436 & 0.670 & 0.836 & 1.000 \\
NANL & 10.831 & 8.073 & 0.000 & 5.000 & 9.000 & 15.000 & 51.000 \\
LNANL & 2.204 & 0.797 & 0.000 & 1.792 & 2.303 & 2.773 & 3.951 \\
ANNMAR & 0.111 & 0.545 & -1.000 & -0.226 & 0.015 & 0.306 & 2.000 \\
ANNTURN & 0.212 & 0.175 & 0.000 & 0.092 & 0.159 & 0.274 & 0.860 \\
DFORFIRM & 0.089 & 0.285 & 0.000 & 0.000 & 0.000 & 0.000 & 1.000 \\
EP & 0.006 & 0.086 & -0.217 & -0.015 & 0.031 & 0.056 & 0.166 \\
DP & 0.007 & 0.015 & 0.000 & 0.000 & 0.000 & 0.007 & 0.090 \\
BP & 0.415 & 0.292 & -0.210 & 0.215 & 0.362 & 0.559 & 1.500 \\
CNI & 0.020 & 0.133 & -0.400 & -0.012 & 0.008 & 0.031 & 0.820 \\
SGR & 0.284 & 0.676 & -0.600 & 0.025 & 0.138 & 0.325 & 4.800 \\
SPINDX & 0.486 & 0.500 & 0.000 & 0.000 & 0.000 & 1.000 & 1.000 \\
INTAN & 0.150 & 0.186 & 0.000 & 0.003 & 0.065 & 0.239 & 0.777 \\
LEV & 0.209 & 0.213 & 0.000 & 0.012 & 0.161 & 0.329 & 0.950 \\
STD & 0.031 & 0.017 & 0.000 & 0.019 & 0.027 & 0.039 & 0.080 \\
BETA & 1.114 & 0.600 & -0.626 & 0.682 & 1.060 & 1.503 & 2.874 \\
TIME & 15.088 & 15.543 & 0.167 & 5.175 & 9.758 & 18.754 & 81.999 \\
LTIME & 2.406 & 0.862 & 0.154 & 1.820 & 2.376 & 2.983 & 4.419 \\
\hline & & & & & & & \\
& & & & & & & \\
& & & & & & &
\end{tabular}


TABLE 2 (Continued)

Descriptive Statistics of Conference and Firm Characteristics

Table 2 presents descriptive statistics for the conference and firm characteristics. The number of observations for each of the variables is 95,105. DPRODMKT equals 1 if the presentation was at a product market-focused conference, 0 otherwise. DCAPMKT_TOP equals 1 if the presentation was at a top brokerage firm, 0 otherwise. $D M O N C E N$ equals 1 if the presentation was at a money center location, 0 otherwise. DDEST equals 1 if the presentation was at a destination location, 0 otherwise. DNONUS equals 1 if the presentation was held outside of the U.S., 0 otherwise. NINDUS is measured as the number of Fama-French industries (30 categories) represented at the conference. DINDUS_CONF equals 1 if the presentation was at an industry-focused conference, 0 otherwise. We define an industry-focused conference as having fewer than four industries represented at the conference. CONFSIZE is measured as the number of presentations that occur at the conference. LCONFSIZE is the log of one plus CONFSIZE. PRIORPRES is the number of conference presentations given by the firm in the past ninety days. LPRIORPRES is the log of one plus PRIORPRES. DINFO_EVENT equals 1 if an earnings announcement, management forecast, and/or Form 8-K filing (including Form 6-K filings for foreign registrants) occurred within the three-day window surrounding the presentation, 0 otherwise. $M V$ is market value in millions (from CRSP) measured 30 days before the conference presentation. $L M V$ is the $\log$ of $M V$. PIH is the percentage ownership by institutional investors, defined as total shares owned by institutions divided by the total shares outstanding, for the most recent calendar quarter end prior to the conference presentation. $N A N L$ is the number of unique analysts issuing an earnings forecast for any horizon during the calendar quarter prior to the conference presentation. $L N A N L$ is the log of one plus $N A N L$. For both $P I H$ and $L N A N L$, we assume the variable has a value of zero for any period when the company is listed on an exchange but there is no data available. ANNMAR is the buy-and-hold market-adjusted stock return over the year prior to 30 days before the presentation. ANNTURN is the average monthly share turnover, computed as volume divided by shares outstanding, for the year prior to 30 days before the presentation. DFORFIRM is an indicator variable set to 1 if the company is headquartered outside the U.S., 0 otherwise. $E P$ is the earnings-to-price ratio at fiscal year-end (FYE) prior to presentation. $D P$ is the dividend-toprice ratio at FYE prior to presentation. $B P$ is the book-to-price ratio at FYE prior to presentation. $C N I$ is the change in net income, deflated by market value at FYE prior to presentation. $S G R$ is the sales growth at FYE prior to presentation. SPINDX is the indicator for listing on any S\&P index at FYE prior to presentation. INTAN is the intangible assets/total assets at FYE prior to presentation. $L E V$ is the leverage at FYE prior to presentation. STD is the standard deviation of stock returns (from CRSP) for year prior to presentation. BETA is the beta (from CRSP) of the stock for year prior to presentation. TIME is the number of years the company has been listed. LTIME is the $\log$ of TIME. 
TABLE 3

Mean and Median Stock Market Reactions during Windows around the Presentation Date

\begin{tabular}{llccrc} 
Variable & Window & Mean & Median & Pct. > 0 & $\mathrm{~N}$ \\
\hline ABS_SAR & $(-7,-5)$ & $0.015^{* * *}$ & $-0.272^{* * * *}$ & $38.0 \%$ & 95,103 \\
& $(-4,-2)$ & $0.036^{* * * *}$ & $-0.261^{* * * *}$ & $38.7 \%$ & 95,104 \\
& $(-1,+1)$ & $0.076^{* * * *}$ & $-0.228^{* * *}$ & $40.4 \%$ & 95,105 \\
& $(-2,+4)$ & $-0.015^{* * *}$ & $-0.279^{* * *}$ & $37.5 \%$ & 95,103 \\
& $(-5,+7)$ & $-0.016^{* * *}$ & $-0.287^{* * *}$ & $37.2 \%$ & 95,103 \\
ABN_TURN & & & & \\
& $(-7,-5)$ & $-0.040^{* * *}$ & $-0.185^{* * *}$ & $40.0 \%$ & 95,103 \\
& $(-4,-2)$ & $0.030^{* * * *}$ & $-0.158^{* * *}$ & $41.4 \%$ & 95,104 \\
& $(-1,+1)$ & $0.148^{* * *}$ & $-0.095^{* * *}$ & $44.6 \%$ & 95,105 \\
& $(-2,+4)$ & $-0.031^{* * *}$ & $-0.160^{* * *}$ & $41.1 \%$ & 95,103 \\
& $(-5,+7)$ & $-0.056^{* * *}$ & $-0.175^{* * *}$ & $40.6 \%$ & 95,103 \\
\hline
\end{tabular}

$*, * *, * * *$ Significantly different from zero at the $0.10,0.05$, and 0.01 level, respectively, using a two-tailed test (means) and a Wilcoxon signed rank test (medians).

Table 3 provides means and medians of stock market reaction variables during various three-day windows before and after firms' conference presentations. Day 0 is the day on which each firm makes its presentation. The absolute value of size-adjusted returns $\left(A B S_{-} S A R\right)$ is defined as the absolute value of three-day size-adjusted returns less the mean absolute value of three-day size-adjusted returns during estimation period, divided by the standard deviation of the absolute values during the estimation period. Abnormal share turnover $\left(A B N \_T U R N\right)$ is defined as the three-day volume divided by shares outstanding, less the average three-day turnover in the estimation period, times 100 . The estimation period begins 120 days prior to the presentation and ends 30 days prior to the presentation. 
TABLE 4

Regressions of Stock Market Reactions during the Three-Day Window around the Presentation Date on Conference Characteristics and Control Variables

\begin{tabular}{|c|c|c|}
\hline Variable & $A B N \_S A R$ & ABN_TURN \\
\hline DPRODMKT & $0.070^{* *}$ & $0.127^{* *}$ \\
\hline DCAPMKT_TOP & $0.034^{* *}$ & $0.091^{* *}$ \\
\hline DDEST & $0.053^{* *}$ & $0.186^{* * *}$ \\
\hline DMONCEN & $0.073^{* * *}$ & $0.156^{* * *}$ \\
\hline DNONUS & 0.016 & -0.001 \\
\hline LCONFSIZE & $0.020^{* * *}$ & $0.037^{* *}$ \\
\hline DINDUS_CONF & $0.044^{* *}$ & 0.064 \\
\hline LPRIORPRES & $-0.016^{*}$ & 0.031 \\
\hline DINFO_EVENT & $0.280^{* * *}$ & $0.733^{* * *}$ \\
\hline$L M V$ & $-0.019^{* * * *}$ & -0.001 \\
\hline$P I H$ & 0.032 & $0.499^{* * * *}$ \\
\hline$L N A N L$ & $-0.018^{* *}$ & 0.017 \\
\hline$A N N M A R$ & $-0.020^{* *}$ & $0.241^{* * *}$ \\
\hline ANNTURN & $-0.141^{* * *}$ & $-2.136^{* * *}$ \\
\hline DFORFIRM & 0.015 & $0.070^{*}$ \\
\hline$E P$ & -0.061 & 0.230 \\
\hline$D P$ & $-0.986^{* *}$ & $-3.182^{* * *}$ \\
\hline$B P$ & -0.008 & -0.009 \\
\hline$C N I$ & 0.025 & -0.003 \\
\hline$S G R$ & $0.017^{* *}$ & 0.033 \\
\hline SPINDX & 0.003 & $-0.062^{* *}$ \\
\hline INTAN & -0.020 & -0.038 \\
\hline$L E V$ & 0.014 & $0.108^{*}$ \\
\hline STD & $-1.370^{* *}$ & $2.484^{*}$ \\
\hline BETA & $0.017^{*}$ & $0.111^{* * *}$ \\
\hline LTIME & -0.003 & $-0.056^{* * *}$ \\
\hline YEAR EFFECTS & Included & Included \\
\hline INDUSTRY EFFECTS & Included & Included \\
\hline $\mathrm{N}$ & 95,105 & 95,105 \\
\hline Adjusted $\mathrm{R}^{2}$ & 0.011 & 0.036 \\
\hline
\end{tabular}

$*, * *, * * *$ Significantly different from zero at the $0.10,0.05$, and 0.01 level, respectively, using a two-tailed test based on two-way clustered standard errors, with clustering at the firm and conference level and bootstrapping using the jackknife method 


\section{TABLE 4 (Continued) \\ Regressions of Stock Market Reactions during the Three-Day Window around the Presentation Date on Conference Characteristics and Control Variables}

Table 4 presents regressions of $A B S \_S A R$ and $A B N \_T U R N$ during the presentation window $(-1,+1)$ on the set of conference characteristics and control variables. The absolute value of size-adjusted returns $\left(A B S \_S A R\right)$ is defined as the absolute value of three-day size-adjusted returns less the mean absolute value of three-day size-adjusted returns during estimation period, divided by the standard deviation of the absolute values during the estimation period. Abnormal share turnover $\left(A B N \_T U R N\right)$ is defined as the three-day volume divided by shares outstanding, less the average three-day turnover in the estimation period, times 100. The estimation period begins 120 days prior to the presentation and ends 30 days prior to the presentation. DPRODMKT equals 1 if the presentation was at a product market-focused conference, 0 otherwise. DCAPMKT_TOP equals 1 if the presentation was at a top brokerage firm, 0 otherwise. DDEST equals 1 if the presentation was at a destination location, 0 otherwise. DNONUS equals 1 if the presentation was held outside of the U.S., 0 otherwise. DMONCEN equals 1 if the presentation was at a money center location, 0 otherwise. LCONFSIZE is the log of one plus the number of presentations that occur at the conference. DINDUS_CONF equals 1 if the presentation was at an industry-focused conference, 0 otherwise. We define an industry-focused conference as having fewer than four industries represented at the conference. LPRIORPRES is the log of one the number of conference presentations given by the firm in the past ninety days. DINFO_EVENT equals 1 if an earnings announcement, management forecast, and/or Form 8-K filing occurred (including Form 6-K filings for foreign registrants) within the three-day window surrounding the presentation, 0 otherwise. $L M V$ is the log of the market value in millions (from CRSP) measured 30 days before the conference presentation. $P I H$ is the percentage ownership by institutional investors, defined as total shares owned by institutions divided by the total shares outstanding, for the most recent calendar quarter end prior to the conference presentation. $L N A N L$ is the log of one plus the number of unique analysts issuing an earnings forecast for any horizon during the calendar quarter prior to the conference presentation. For both PIH and $L N A N L$, we assume the variable has a value of zero for any period when the company is listed on an exchange but there is no data available. ANNMAR is the buy-and-hold market-adjusted stock return over the year prior to 30 days before the presentation. ANNTURN is the average monthly share turnover, computed as volume divided by shares outstanding, for the year prior to 30 days before the presentation. DFORFIRM is an indicator variable set to 1 if the company is headquartered outside the U.S., 0 otherwise. $E P$ is the earnings-to-price ratio at fiscal year-end (FYE) prior to presentation. $D P$ is the dividend-to-price ratio at FYE prior to presentation. $B P$ is the book-to-price ratio at FYE prior to presentation. $C N I$ is the change in net income, deflated by market value at FYE prior to presentation. $S G R$ is the sales growth at FYE prior to presentation. SPINDX is the indicator for listing on any S\&P index at FYE prior to presentation. INTAN is the intangible assets/total assets at FYE prior to presentation. $L E V$ is the leverage at FYE prior to presentation. $S T D$ is the standard deviation of stock returns (from CRSP) for year prior to presentation. BETA is the beta (from CRSP) of the stock for year prior to presentation. LTIME is the log of one plus the number of years the company has been listed. We include year and industry fixed effects but do not report them in the table. 
TABLE 5

Mean and Median Changes in Analyst Following and Institutional Holdings for Quarters

Subsequent to the Presentation Date

\begin{tabular}{llrrr} 
Variable & Mean & Median & Pct. > 0 & \multicolumn{1}{c}{$\mathrm{N}$} \\
\hline CNANL2 & $0.201^{* * * *}$ & $0.000^{* * * *}$ & $39.4 \%$ & 94,321 \\
CNANL4 & $0.326^{* * *}$ & $0.000^{* * *}$ & $44.9 \%$ & 91,860 \\
& & & \\
CPIH2 & $0.017^{* * * *}$ & $0.010^{* * * *}$ & $59.5 \%$ & 94,321 \\
CPIH4 & $0.028^{* * *}$ & $0.020^{* * *}$ & $62.5 \%$ & 91,860 \\
\hline
\end{tabular}

$*$, **, *** Significantly different from zero at the $0.10,0.05$, and 0.01 level, respectively, using a two-tailed test (means) and a Wilcoxon signed rank test (medians).

Table 5 presents means and medians for changes in analyst following and institutional holdings for two and four quarters after the conference presentation (quarter 0). $N A N L$ is the number of unique analysts issuing earnings forecasts for any horizon for the firm during a calendar quarter. CNANL2 is the difference between $N A N L$ in the first full calendar quarter after the presentation and the quarter prior to the presentation. Similarly, CNANL4 is the difference between $N A N L$ three full calendar quarters after the presentation and the quarter prior to the presentation (i.e., the same calendar quarters one year apart). $P I H$ is the percentage ownership by institutional investors, defined as total shares owned by institutions divided by the total shares outstanding. $\mathrm{CPIH} 2$ is the difference between $P I H$ at the end of the calendar quarter subsequent to the presentation and the end of the quarter prior to the presentation. $\mathrm{CPIH} 4$ is the difference between $\mathrm{PIH}$ three full calendar quarters after the presentation and the quarter prior to the presentation (i.e., the same calendar quarters one year apart). 
TABLE 6

Regressions of Changes in Analyst Following and Institutional Holdings Subsequent to the Presentation Date on Conference Characteristics and Control Variables

\begin{tabular}{|c|c|c|c|c|}
\hline Variable & CNANL2 & CNANLA & $\mathrm{CPIH} 2$ & $\mathrm{CPIH} 4$ \\
\hline DPRODMKT & $-0.116^{* * * *}$ & $-0.263^{* * * *}$ & -0.001 & -0.001 \\
\hline DCAPMKT_TOP & $-0.064^{* *}$ & $-0.062^{*}$ & $0.002^{*}$ & $0.005^{* * *}$ \\
\hline$D D E S T$ & -0.025 & 0.020 & 0.003 & 0.000 \\
\hline DMONCEN & 0.011 & -0.059 & 0.000 & 0.001 \\
\hline DNONUS & $-0.138^{* *}$ & $-0.153^{*}$ & $-0.004^{*}$ & $-0.006^{*}$ \\
\hline LCONFSIZE & 0.006 & 0.020 & $0.001^{* * *}$ & $0.002^{* *}$ \\
\hline DINDUS_CONF & 0.044 & $0.130^{* * * *}$ & 0.000 & -0.001 \\
\hline LPRIORPRES & $0.177^{* * * *}$ & $0.341^{* * *}$ & $0.002^{* * * *}$ & $0.003^{* * *}$ \\
\hline DINFO_EVENT & -0.029 & -0.027 & $-0.002^{* * *}$ & $-0.003^{* *}$ \\
\hline$L M V$ & $0.153^{* * *}$ & $0.250^{* * * *}$ & $-0.004^{* * *}$ & $-0.006^{* * *}$ \\
\hline PIH & $1.028^{* * * *}$ & $1.646^{* * *}$ & $-0.098^{* * *}$ & $-0.151^{* * *}$ \\
\hline LNANL & $-0.818^{* * * *}$ & $-1.440^{* * * *}$ & $0.009^{* * *}$ & $0.014^{* * *}$ \\
\hline ANNMAR & $0.475^{* * *}$ & $0.934^{* * * *}$ & $0.018^{* * *}$ & $0.023^{* * *}$ \\
\hline ANNTURN & $0.774^{* * * *}$ & $1.129^{* * * *}$ & $-0.011^{* *}$ & $-0.029^{* * *}$ \\
\hline DFORFIRM & 0.065 & -0.013 & $-0.033^{* * *}$ & $-0.050^{* * *}$ \\
\hline$A B N \_S A R$ & $-0.039^{* * *}$ & $-0.058^{* * *}$ & $-0.003^{* * *}$ & $-0.003^{* * *}$ \\
\hline$A B N \_T U R N$ & $0.031^{* * *}$ & $0.056^{\text {**** }}$ & $0.002^{* * *}$ & $0.002^{* * *}$ \\
\hline$S A R$ & $0.451^{* * * *}$ & $1.240^{* * * *}$ & $0.076^{* * *}$ & $0.099^{* * *}$ \\
\hline$E P$ & $0.682^{* * * *}$ & $1.122^{* * * *}$ & $0.050^{* * *}$ & $0.093^{* * *}$ \\
\hline$D P$ & 0.534 & -0.525 & $-0.182^{* * *}$ & $-0.286^{* * *}$ \\
\hline$B P$ & $-0.552^{* * *}$ & $-0.913^{* * * *}$ & $0.006^{* * *}$ & $0.011^{* * *}$ \\
\hline CNI & $-0.274^{* * *}$ & $-0.464^{* * * *}$ & -0.001 & 0.000 \\
\hline$S G R$ & $0.078^{* * * *}$ & 0.047 & $-0.002^{* *}$ & $-0.005^{* * *}$ \\
\hline SPINDX & $-0.099^{* * *}$ & -0.096 & $0.008^{* * *}$ & $0.013^{* * *}$ \\
\hline INTAN & -0.070 & -0.221 & 0.002 & -0.001 \\
\hline$L E V$ & $-0.185^{\text {*** }}$ & -0.142 & $0.014^{* * *}$ & $0.024^{* * *}$ \\
\hline$S T D$ & $-3.278^{*}$ & $-8.470^{* * * *}$ & $-0.360^{* * *}$ & $-0.313^{* * *}$ \\
\hline BETA & $0.160^{* * *}$ & $0.250^{* * *}$ & 0.002 & $0.004^{* *}$ \\
\hline LTIME & $-0.136^{* * *}$ & $-0.219^{* * * *}$ & $-0.004^{* * *}$ & $-0.006^{* * *}$ \\
\hline YEAR EFFECTS & Included & Included & Included & Included \\
\hline INDUSTRY EFFECTS & Included & Included & Included & Included \\
\hline $\mathrm{N}$ & 94,321 & 91,860 & 94,321 & 91,860 \\
\hline Adjusted $\mathrm{R}^{2}$ & 0.090 & 0.136 & 0.060 & 0.082 \\
\hline
\end{tabular}

$*, * *, * * *$ Significantly different from zero at the $0.10,0.05$, and 0.01 level, respectively, using a two-tailed test based on two-way clustered standard errors, with clustering at the firm and conference level and bootstrapping using the jackknife method 


\section{TABLE 6 (Continued)}

\section{Regressions of Changes in Analyst Following and Institutional Holdings Subsequent to the Presentation Date on Conference Characteristics and Control Variables}

Table 6 provides regressions of changes in analyst following and institutional holdings on conference and firm characteristics. $N A N L$ is the number of unique analysts issuing earnings forecasts for any horizon for the firm. CNANL2 (CNANL4) is the difference between NANL in the first (third) full calendar quarter after the presentation and the quarter prior to the presentation. $P I H$ is the percentage ownership by institutional investors, defined as total shares owned by institutions divided by the total shares outstanding. $\mathrm{CPIH} 2(\mathrm{CPIH} 4)$ is the difference between $\mathrm{PIH}$ at the end of the first (third) calendar quarter subsequent to the presentation and the end of the quarter prior to the presentation. DPRODMKT equals 1 if the presentation was at a product market-focused conference, 0 otherwise. DCAPMKT_TOP equals 1 if the presentation was at a top brokerage firm, 0 otherwise. DDEST equals 1 if the presentation was at a destination location, 0 otherwise. DNONUS equals 1 if the presentation was held outside of the U.S., 0 otherwise. DMONCEN equals 1 if the presentation was at a money center location, 0 otherwise. LCONFSIZE is the log of one plus the number of presentations that occur at the conference. DINDUS_CONF equals 1 if the presentation was at an industry-focused conference, 0 otherwise. We define an industry-focused conference as having fewer than four industries represented at the conference. LPRIORPRES is the log of one the number of conference presentations given by the firm in the past ninety days. DINFO_EVENT equals 1 if an earnings announcement, management forecast, and/or Form 8-K filing (including Form 6-K filings for foreign registrants) occurred within the three-day window surrounding the presentation, 0 otherwise. $L M V$ is the $\log$ of the market value in millions (from CRSP) measured 30 days before the conference presentation. PIH is the percentage ownership by institutional investors, defined as total shares owned by institutions divided by the total shares outstanding, for the most recent calendar quarter end prior to the conference presentation. LNANL is the log of one plus the number of unique analysts issuing an earnings forecast for any horizon during the calendar quarter prior to the conference presentation. For both $P I H$ and $L N A N L$, we assume the variable has a value of zero for any period when the company is listed on an exchange but there is no data available. ANNMAR is the buy-and-hold market-adjusted stock return over the year prior to 30 days before the presentation. ANNTURN is the average monthly share turnover, computed as volume divided by shares outstanding, for the year prior to 30 days before the presentation. DFORFIRM is an indicator variable set to 1 if the company is headquartered outside the U.S., 0 otherwise. $A B S \_S A R$ is the absolute value of size-adjusted returns, defined as the absolute value of three-day size-adjusted returns less the mean absolute value of three-day size-adjusted returns during estimation period, divided by the standard deviation of the absolute values during the estimation period. ABN_TURN is the abnormal share turnover, defined as the three-day volume divided by shares outstanding, less the average three-day turnover in the estimation period, times 100. The estimation period begins 120 days prior to the presentation and ends 30 days prior to the presentation. $S A R$ is the three-day size-adjusted returns surrounding the presentation. EP is the earnings-to-price ratio at fiscal year-end (FYE) prior to presentation. $D P$ is the dividend-to-price ratio at FYE prior to presentation. $B P$ is the book-to-price ratio at FYE prior to presentation. $C N I$ is the change in net income, deflated by market value at FYE prior to presentation. $S G R$ is the sales growth at FYE prior to presentation. SPINDX is the indicator for listing on any S\&P index at FYE prior to presentation. INTAN is the intangible assets/total assets at FYE prior to presentation. $L E V$ is the leverage at FYE prior to presentation. STD is the standard deviation of stock returns (from CRSP) for year prior to presentation. BETA is the beta (from CRSP) of the stock for year prior to presentation. LTIME is the log of one plus the number of years the company has been listed. We include year and industry fixed effects but do not report them in the table. 